\title{
Sorcery, Heresy, and the Authority of the Church
}

\author{
Allison Bailey
}

The Church in medieval Europe had a stronghold on the knowledge that was provided to the community. As a means of maintaining their superior position they persecuted heretics, including sorcerers, who had allegedly acted against the Church. However, sorcery was not originally associated with heresy. There was a shifting mentality among Church officials towards that use of magic that resulted in sorcery transitioning from an error to a heretical behaviour. Understanding the various forms of heresy including sorcery, is essential to knowing how the Church was able to impose orthodoxy on the people of Europe. Orthodoxy among the laity was essential to the Church maintaining its superiority within Europe. Sorcery and magic were a threat to the Church, not only because lay people were circumventing the Church by appealing to otherworldly powers, but also because the Church would lose their control over the souls of the people.

The meaning of heresy is important for analyzing the documents of the Church regarding heretics and heretical behaviour. The original meaning of heresy, haeresis, was used to label choice in Ancient Greece before it was adopted into the Latin vocabulary. ${ }^{1}$ As time went on, the meaning of the word shifted to designate the Greek and Roman schools of thought. Once Christendom was thoroughly in place, the term came to mean learning or teaching against church doctrine. ${ }^{2}$ However, being labeled a heretic was not an automatic result of someone acting against the Church, they had the opportunity to be corrected, cautioned against their behaviour, or publicly denounced as a means of dissuading any further heresies. A heretic therefore, was someone who had been caught acting against the Church and was taught how to behave correctly, but continued to behave against church doctrine. ${ }^{3}$ Heresy also largely stemmed from people wanting to interpret the Bible their own way, which was a form of dissent and took power away from the Church. ${ }^{4}$ A medieval author, Robert Gosseteste, the Bishop Lincoln, defined heresy as "an opinion chosen by human faculties, contrary to sacred scripture, openly held, and pertinaciously defended." ${ }^{5}$ This excerpt demonstrates that the act of heresy was purposeful and done knowingly against the Church and in an effort to oppose the Church. Many of the groups who chose to interpret the Bible their own way, including the Cathars of the twelfth century and the Lollards of the fifteenth century, did so because of the

\footnotetext{
${ }^{1}$ Edward Peters, Europe and the Middle Ages, $4^{\text {th }}$ ed. (Upper Saddle River: Pearson Prentice Hall, 2004), 283.

${ }^{2}$ Ibid.

${ }^{3}$ Ibid.

${ }^{4}$ R. N. Swanson, Religion and Devotion in Europe c. 1215-1515 (Cambridge: Cambridge University Press, 1995),272.

${ }^{5}$ Ibid.
} 
contradictory and unstable nature of Christianity. ${ }^{6}$ The Cathars especially posed a serious problem for the Church because they were able to gather a sizeable following. They preached that everything that was the material world was evil, causing great concern within the Church. ${ }^{7}$ Another teaching of the Cathars was that souls were trapped in the material body, the world being hell and the souls needed to escape. For the Church, this would imply that it too was evil both as an institution and those who occupied the clergy; the Church's power over the populace was corrupted by its materiality. These dissenters, and others who felt that they needed something more from their religion, indicate that the Church was not sensitive to the needs of the people, rather they were more concerned with what the laity were doing wrong.

With the rise of heretical sects, including the Cathars, the Church needed to react and impose strict canonical laws to secure their position of power. The Fourth Lateran Council of 1215 marked the official definition and need for persecution of heretical behaviour. The council was made up of prominent church leaders, including the Pope, to establish church laws that that laity across Europe were meant to abide by. Multiple groups, including the Cathars, were interpreting the Bible for themselves, and no longer required the Church. This threatened the conformist nature that had been established and preserved for hundreds of years. The canons that were the result of the council outlined the distinctions in law of the difference between orthodoxy and heresy, ensuring these two were clearly different. ${ }^{8}$ Canon Three of the Fourth Lateran Council was written specifically about heresy and "condemning all heretics under whatever names they may be known, for while they have different faces, they are nevertheless bound to each other by their tails." ${ }^{\prime \prime}$ This excerpt was meant to demonstrate that heretics were not a specific people, but that heresy could have been committed by anyone, and that all heretics were linked by their devilish ways. The Canon describes the punishments that would be carried out against heresy and mentions that it is the secular authority who will punish the heretics. These punishments included that all property was to be confiscated, and that heresy could even result in excommunication. ${ }^{10}$ Excommunication was the ultimate punishment for the medieval individual because it barred them from entering heaven. The loss of property meant that the individual was excluded from the community, and in conjunction with excommunication, ensured that the person was destined to a life and afterlife of suffering. Additionally, Canon Three details that rulers who have heretics in their realm faced excommunication if they were unable to rid the area of these dissenters. ${ }^{11}$ The

\footnotetext{
${ }^{6}$ Swanson, Religion and Devotion, 283-4.

${ }^{7}$ Norman Cohn, "The Demonisation of Medieval Heretics," in The Witchcraft Reader, $2^{\text {nd }}$ ed., ed. Darren Oldridge (New York: Routledge, 2008), 33.

${ }^{8}$ Edward Peters, Middle Ages Series: Heresy and Authority in Medieval Europe (Philadelphia: University of Pennsylvania Press, 1980), 167.

9 “Fourth Lateran Council," in Middle Ages Series, ed. Peter Edwards, 175.

${ }^{10}$ Ibid.

11 "Fourth Lateran Council," in Middle Ages Series, ed. Peter Edwards, 175.
} 
Church was exercising their authority over the secular world by ensuring that they had the power over the king and other rulers. The king, under threat of excommunication, was at the mercy of the Church, and therefore had to abide by their rules. There was also an obvious power struggle between the Church and secular authorities, exemplified by the Church insisting that kings adhere to their demands. The entire community was subject to the possibility of excommunication, including anyone who helped believed in the preaching of a heretic. ${ }^{12}$ The Church demanded vigilance on the part of the bishops because of the strict rules placed on society to ensure that no one fell into heresy, the bishops were also meant to control the faith of the people by imposing Canon Law and not allowing others to preach against Church doctrine. ${ }^{13}$ The Fourth Lateran Council is significant to the study of heresy because it was the first Canon Law about heretical behaviour and the impending punishment for heretics, through time the use of magic was placed under the aegis of heresy. With the new canon laws, the Church had increased power over the people and marked longstanding behaviours as heretical. Magic use had become engrained in many practices among laity because in the early years of the Church many pagan rituals had been integrated into Catholic practices. This shift resulted in centuries of witch hunting that killed thousands of innocents.

The Fourth Lateran Council was not the first church gathering to discuss the issues of heresy. Several meetings were held in centuries before, and these gatherings also resulted in writings by clergy to discuss the differences between error and heresy. One such writer was Burchard of Worms (ca. 950-1025). Before sorcery became equated to heresy it was considered an error. Burchard of Worms wrote a document about errors that people could commit and the penance related to each type of wrongdoing. The document "Corrector and Doctor" was one of the largest collections of errors, and there was an entire section that discussed sorcery. Several sections of the document were concerned with the magical arts, including a description of women who ride around at night hailing Satan. This activity was still only considered an error and resulted in two years of penance in the form of fasting during holy days. ${ }^{14}$ This example is especially important because this theme would be carried through the centuries to the early modern European witchcraft trials that would kill many women. Burchard of Worms, however, merely sees this activity as an error, not heresy, and suggested that the transgressor perform penance.

With the rise of dissenters towards the Church, as well as the increasingly severe punishments established in the Fourth Lateran Council, there was a need to find and persecute those who were acting contrary to Church teachings. As a response to heretical behaviour, the inquisition was implemented to find the heretics and put an end to their wrongdoing. The inquisitorial process began with an appointed church official coming to a town suspected of having heretics, the official would teach a sermon denouncing heresy, and then would ask any heretics of those

\footnotetext{
12 Ibid.

${ }^{13}$ Ibid.

${ }^{14}$ Bouchard of Worms, "Corrector and Doctor (c. 1008-12)," in Medieval Popular Religion, 1000-1500: A Reader, ed. John Shinners (Peterborough: Broadview Press, 2007), 462-3.
} 
who knew of heretics to come forward and confess. ${ }^{15}$ Once people came forward, or were brought in, the questioning would begin. Heretics who would not repent their beliefs would suffer harsher punishments than confessed heretics. The inquisitors had an arsenal of tactics that they could employ to acquire a confession, including psychological tricks, as well as threats against the accused's finances. ${ }^{16}$ The inquisitors would also use extreme measures to obtain confessions, often by giving the accused heretic over to the secular authorities who would then torture the victim. Those found guilty of heresy after the inquisition were to become social pariahs. They lost their homes, could not be buried in church land, and could not inherit or leave any property in a will. ${ }^{17}$ Confirmed heretics were also made to wear special markings on their clothes, therefore the whole community would be reminded of the Church's severity in the punishment of those who acted against them. In the most severe cases, heretics were put to death. ${ }^{18} \mathrm{~A}$ fine line divided orthodoxy and heresy, the inquisitors were responsible for distinguishing the difference, but this often led to error being interpreted as heresy. ${ }^{19}$ The ultimate motivation for the inquisition was to correct incorrect behaviours, beliefs, and practices to ensure that there would be no further damage to Church doctrine. As sorcery began to become more commonly used, there was an increasingly large number of heretics accused of using magic. These heretics were seen as the ultimate threat to church orthodoxy because they were appealing to supernatural forces, rather than scripture.

The desire for knowledge was a constant power struggle between the lay people and the Church. Heresy was a threat to the Church and their power, but not all heresies were treated equally. Heretics were only seen as heretics because they had lost their battle against the Church for more power. ${ }^{20}$ The inquisitorial process that was imposed to find heretics became a method of repression keeping documents as "its ultimate source of power."21 The different methods used to find heretics and combat heresy were outline in different church documents and doctrine. However, by maintaining a stronghold on the available documents, the laity were not made aware of the differences between possible crimes against the Church. This lack of knowledge would lead to many people attempting to find their own solutions to existential issues that they were facing on a daily basis.

There were two common uses of magic linked to heresy in the Middle Ages: sorcery and witchcraft. Before witchcraft became a popular concept, sorcery was believed to be a suspicious use of magic, sometimes even a criminal act because it

\footnotetext{
${ }^{15}$ Peters, Europe and the Middle Ages, 289.

${ }^{16}$ Ibid.

${ }^{17}$ Ibid.

${ }^{18}$ Swanson, Religion and Devotion, 273.

${ }^{19}$ Ibid.

${ }^{20} \mathrm{Ibd}$.

${ }^{21}$ Lucy Sackville, Heresy and Inquisition in the Middle Ages, Volume 1: Heresy and Heretics in the Thirteenth Century: The Textual Representations (Suffolk: Boydell \& Brewer, 2001), 114.
} 
was considered to be harmful. ${ }^{22}$ Early conceptions of magic were related to the pagan belief system popular throughout Europe before the spread in popular Christianity. ${ }^{23}$ There was a shift in conceptualizing magic and sorcery between the fourteenth and fifteenth centuries that changed the understanding of different elements of magic, including how people interacted with magic and how they could manipulate it, and the possible goals of manipulation; essentially how humans and magic interacted and the relationship between them. ${ }^{24}$ The idea of magic was not new during the medieval period. Magic dates back to pre-modern cultures in Western Europe. At the beginning of the Christian era in the Mediterranean region, magic was legally neutral and used in either harmful or beneficial ways; the GrecoRomans only persecuted those who practiced harmful magic. ${ }^{25}$ Maleficent magic has always been linked to demonic forces in the Christian doctrine. As Christendom began to spread, the "daimons" that were called on to aid in sorcery became "demons" to the Christian church. Not all "daimons" were evil, whereas demons were Satan's soldiers and completely malicious. ${ }^{26}$ The Fourth Lateran Council also provided physical traits of heretics, including tails and distorted faces, which would also become associated with artistic renderings of demons. The correlation between the two would suggest that they were one in the same. Heretics were acting in accordance with demons. Sorcerers in the medieval period were not considered to be practicers of evil, rather they had been tempted and lied to by Satan and therefore were his victims. The Church dealt with sorcerers through correction and penance. The thirteenth century saw the rise of more learned elite members of society who were studying alchemy, as well as having more knowledge of demonic magic, a type of magic that was found in Arabic, Jewish, and Greek texts, these works were highly feared by the Church. ${ }^{27}$ The elite form of magic was necromancy, the use of magic to talk to and interact with spirits and the deceased. It was also considered to be a darker more sinister form of magic. All members of society, including many of the ecclesiastical order, had access to and used "common spells, charms, blessings, potions, powders, and talismans." 28 However, the Church did not deny that there may have been a demonic power in those forms of magic, and the populace no doubt believed it too because "the church told them to do so." ${ }^{29}$ Pope John XXII feared sorcery, especially among the higher members of the ecclesiastical order and as a result throughout his papacy the Church became more suspicious of sorcery. In 1326 "Pope John XXII issued the decree Super illius specula" stating that any one who took

\footnotetext{
22 Michael D. Bailey, '“From Sorcery to Witchcraft: Clerical Conception of Magic in the Later Middle Ages", Speculum 76, no. 4 (2001): 960-999.

${ }^{23}$ Michael D. Bailey, "The Age of Magicians: Periodization in the History of European Magic," Magic, Rituals, and Witchcraft 3, no. 1 (2008): 5.

${ }^{24}$ Bailey, "From Sorcery to Witchcraft," 963.

${ }^{25}$ Ibid, 960-3.

${ }^{26}$ Ibid.

${ }^{27}$ Ibid., 964.

${ }^{28}$ Ibid., 965.

${ }^{29}$ Ibid.
} 
part in sorcery by invoking death or demons was to be excommunicated and suffer all penalties. ${ }^{30}$ The decree was more intended for sorcery involving "images, rings, mirrors, and phials," items that were used in complex magic, rather than items used on common sorcery, such as "herbs, stones, and simple charms." 31 The distinction between the common sorcery and elite forms of magic were indicative of what the Church was more scared of, however in practice, the laity were the ones who were punished more often.

There were many Popes who were concerned with the need for harsher punishments on sorcery, and heresy as a whole. In the 1230s Pope Gregory IX commanded the implementation of the inquisitorial procedure due to the rise of heresies. The need for the inquisition further demonstrates that there was a challenge for knowledge and this was in direct conflict with the authority of the Church. ${ }^{32}$ Bernard of Gui was an inquisitor between ca. 1303 and 1324 in Toulouse and he wrote on his experiences as an inquisitor, as well as an instructional manual called Practica inquisitionis heretics pravitatis. ${ }^{33}$ Gui was selected by the Pope to conduct the inquisitorial procedures and his book was meant to aid other inquisitors. The book outlined the processes included in the investigations and also outlined different heretical behaviour, as well as how to manage different cases. ${ }^{34}$ Gui had experience dealing with almost all heresies that were common at that time, but he did not write extensively on sorcery. This could be due to the author's attempt to address all heresies in his book, but it could also suggest that sorcery may not have been as significant a crime as compared to other heresies. Gui did not sentence any sorcerers himself during the thousands of trials that he was personally involved in. In Practica, Gui outlines possible inquisition questions to ask if one was to interview a heretic; the questions reflect what Gui though constituted sorcery, which was more closely related to the common forms, not those of the elite that were deemed more harmful. ${ }^{35}$ For example, Gui wrote that inquisitors should ask about magic that could be used to heal, which was the most commonly used form of sorcery. Other common forms were the use of magic to commit theft, find lost items, finding guilty thieves, to help in conception and pregnancy, and to aid in love, all of which Gui wrote about in his manual. Gui also wrote about the items inquisitors should ask about, none of which were related to the demonic sorcery, suggesting that Pope John XXII's fears of sorcery were unfounded. Although Gui only wrote about common magic, he believed it to be linked to demons, which would imply that sorcery was heretical as those who practiced it were appealing to demons, and all forms of sorcery were equally harmful. ${ }^{36}$ Gui's work marks a transition in the

\footnotetext{
${ }^{30}$ Bailey, "From Sorcery to Witchcraft," 966-967.

${ }^{31}$ Ibid., 967.

32 John Stiner, ed., Medieval Popular Religion, 1000-1500: A Reader, $2^{\text {nd }}$ ed. (Peterborough Broadview Press, 2007), 472.

${ }^{33}$ Bailey, "From Sorcery to Witchcraft," 967.

${ }^{34}$ Shinners, Medieval Popular Religion, 472-3.

${ }^{35}$ Bailey, "From Sorcery to Witchcraft," 968.

${ }^{36}$ Bailey, "From Sorcery to Witchcraft," 968-70.
} 
concept of sorcery because now there was no differentiation between what the elites and common people were engaging in.

The portion of the book where Bernard of Gui describes sorcery is rather short and there are few details on what to expect from a sorcerer. Gui lumps all three different classes of magic users into one heretical category in his manual: "the following concerns sorcerers, diviners, and invokers of demons." ${ }^{37}$ Those who used sorcery listed by Gui were said to be everywhere and practice magic due to false superstitions and error because of demonic implications. Those who practice magic were subject to a specific set of questions during the inquisitorial process, especially what the nature of the magic being practiced was, and how often. ${ }^{38}$ Gui makes a point of differentiating between men and women, each of whom having their own specific set of questions. Other considerations Gui outlines include "the quality and condition of the person" because the methods of questioning depended on individuals' place in society. ${ }^{39}$ Interjected into the middle of the questions that were to be asked, Gui shifts the tone of questioning towards practices against the Church that may be harmful to its authority. For example, he says "inquire especially into those things that smack of any possible superstition, irreverence, or insult towards the church's sacraments, most especially towards the sacraments of the Lord's Body, and also toward divine worship in sacred places." 40 This line of questioning about any insult against the Church was a direct attack on their authority because those who chose to ignore the teachers or sacraments were doing so maliciously according to Gui.

A case study of a trial that occurred regarding magic was against Lady Alice Kyteler in 1324. This is one of the earliest cases of witchcraft that was ever tried. Although witchcraft was not yet a popular phenomenon in the medieval period, it was still believed that people, especially women, would work for demons. ${ }^{41}$ Considering the different treatment women were entitled to according to Gui, it is alarming that Kyteler was treated with such severity. However, the treatment of Kyteler and those associated with her is indicative of the egregiousness of her crimes. Lady Alice and her son were thought to be hustlers in their community, Alice's stepchildren held a grudge against her about money they believed was owed to them. The stepchildren brought the accusations of sorcery to the church and had the support of the community. To avoid conviction, Alice fled the town and was subsequently excommunicated; the members of her household, including servants, were killed by association and also some participating in the black magic. ${ }^{42}$ The trial record describes that in the area of Kilkenny there were "many heretic sorcerers employing various kinds of sorcery that had the whiff of assorted heresies about

\footnotetext{
37 “The Inquisitor Bernard of Gui on Sorcery (c. 1323)," in Medieval Popular Religions 1000-1500: A Reader, John Shinners ed. $2^{\text {nd }}$ ed. (Peterborough: Broadview Press, 2007), 473.

${ }^{38}$ Ibid.

${ }^{39}$ Ibid.

${ }^{40}$ Ibid., 474.

${ }^{41}$ Shinners, Medieval Popular Religion, 262.

${ }^{42}$ Ibid.
} 
them," suggesting that sorcery was popular during this time and was considered to be a crime against the church. ${ }^{43}$ The document also describes that Alice and her sorcery companions "would completely reject faith in Christ and the Church," for a period of time to ensure their goals were met "so that during this whole period of they believed nothing that the church believes." 44 Alice and her cohorts were also accused of sacrificing animals by mutilation to demons. They also turned to demons for "counsel and answers." 45 Other rituals included concocting mixtures with "entrails of the cocks they sacrificed [...] with certain disgusting worms, assorted herbs, fingernails taken from dead people and hair from their backsides," as well as diapers of babies who had died not having been baptized; all of which were boiled in a beheaded criminal's skull to inflict pain and death on Christians, also attempting to make people love and hate each other. ${ }^{46}$ The complaint against Alice had been brought forth by her stepchildren who alleged that through magic and sorcery Alice "had killed some of their fathers and had infatuated other," also having convinced them to leave all their belongings to her. ${ }^{47}$ As evidence to the claims of sorcery, the current husband of Alice, John le Poer, had a maidservant give over the keys to open a chest and found the revolting contents listed; the husband was also showing symptoms of being under a sorcerer's spell because "his fingernails fallen off and all the hair on his body gone."48 Part of the trial documents described that Alice had had sexual relations with the demon Son of Art who could manifest himself either as a cat, a black dog, or a black man, Alice would also claim that everything she had was because of this demon. Alice fled but was still tried in absentia, she was deemed "a sorceress, a magician, and a relapsed heretic." ${ }^{49}$ After the trial, on the same day, all of Alice's belongings thought to be of use to her sorcery were destroyed by fire in the public square. One of Alice's companions, Petronilla of Meath, was arrested as a heretic, whipped six time as penance, and then burned alive. She had claimed that she renounced Christ and the church by the instruction of Alice, also taking part in the animal sacrifices to the demon. Petronilla also recited the ingredients to the concoctions adding to the evidence against Lady Alice. She also acted as the messenger for Alice and her demon, she confessed to watching Alice have sexual relations with the demon in the form of three black men, and after had to clean the mess. Petronilla claimed Alice was the most powerful sorceress in all of Ireland and she had learned all her sorcery from Alice. Petronilla refused penance and was

\footnotetext{
43 “The Sorcery Trial of Lady Alice Kyteler (1324)," in Medieval Popular Religion, 1000-1500: A Reader, John Shinners ed. (Peterborough: Broadview Press, 2007), 264.

${ }^{44}$ Ibid.

${ }^{45}$ Ibid.

${ }^{46}$ Ibid.

${ }^{47}$ Ibid., 264-265.

${ }^{48}$ Ibid., 265.

${ }^{49}$ Ibid.
} 
therefore burned before a massive crowd. She was the first sorceress executed by fire in Ireland. ${ }^{50}$

The case study of the Trial of Lady Alice and her sorcery companions is significant to understanding the fear of magic in the medieval period. There are many parallels between the trial, the document of Bernard of Gui, and the Fourth Lateran Council. In the manual of inquisitors, Gui outlines questions regarding the different ingredients that can be used for sorcery, and the trial documents list similar ingredients Gui had written about. Lady Alice had also taught Petronilla to renounce her faith in Christ and by doing so had rejected the sacraments as well, which was outlined by Gui in his manual. The Fourth Lateran Council had described that all lands had to be rid of heretics, and Alice's case is an example of how the community was ensuring that heresy was being eliminated from within.

The shifting conception of sorcery and magic happened gradually as the church's power over Europe spread. Magic as a pagan practice eventually became heresy and was to be dealt with severely because it posed a threat to the authority of the church. Their authority was fragile and needed constant reinforcement from the laity though imposing different mechanism of control and from the compliance of the community of believers. One of the mechanisms of control was the inquisition that was meant to find heresy in communities and put an end to it through the threat of different punishments. The punishments of losing property and excommunication were severe because it left a person completely isolated from all activities of the medieval world. The significance in understanding the different ideas of sorcery is that it demonstrates that the once harmless practice would eventually become an act that drew more suspicion, and would result in the most severe punishment the Church could bestow: excommunication. Sorcery was a threat to the Church because magic took power away from the clergy and invoked demons that could be harmful to others. The loss of authority of the Church would mean that they could not long control the religiosity of the people of Europe, a notion that was not only a fear of the Church, but also the people.

\footnotetext{
50 “The Sorcery Trial of Lady Alice Kyteler (1324)," in Medieval Popular Religion John Shinners ed. 264-6.
} 


\section{Bibliography}

Bailey, Michael D. "The Age of Magicians: Periodization in the History of European Magic." Magic, Ritual, and Witchcraft 3, no. 1 (2008): 1-28.

- _-____—_From Sorcery to Witchcraft: Clerical Conception of Magic in the Later Middle Ages." Speculum 76, no. 4 (2001): 960-999.

Burchard of Worms. "Corrector and Doctor (c. 1008-12)." In Medieval Popular Religion 1000-1500: A Reader. $2^{\text {nd }}$ edition. Edited by John Shinners. Peterborough: Broadview Press, 2007.

Cohn, Norman. "The Demonisation of Medieval Heretics." In The Witchcraft Reader. $2^{\text {nd }}$ edition. Edited by Darren Oldridge. New York: Routledge, 2008.

Peters, Edward. Europe in the Middle Ages. $4^{\text {th }}$ edition. Upper Saddle River: Pearson Prentice Hall, 2004.

- Middle Ages Series: Heresy and Authority in Medieval Europe. Philadelphia : University of Pennsylvania Press, 1980.

"Fourth Lateran Council, 1215." Middle Ages Series: Heresy and Authority in Medieval Europe. Edited by Peter Edwards. Philadelphia: University of Pennsylvania Press, 2011.

Sackvill, Lucy. Heresy and Inquisition in the Middle Ages, Volume 1: Heresy and Heretics in the Thirteenth Century: The Textual Representations. Suffolk: Boydell \& Brewer, 2011.

Shinners, John, editor. Medieval Popular Religion, 1000-1500: A Reader. $2^{\text {nd }}$ edition. Peterborough: Broadview Press, 2007.

“The Inquisitor Bernard of Gui on Sorcery (c. 1323)." In Medieval Popular Relgion, 1000-1500: A Reader. $2^{\text {nd }}$ edition. Edited by John Shinners. Peterborough: Broadview Press, 2007.

“The Sorcery Trial of Lady Alice Kyteler (1324)." In Medieval Popular Relgion, 10001500: A Reader. $2^{\text {nd }}$ edition. Edited by John Shinners. Peterborough: Broadview Press, 2007.

Swanson, R. N. Religion and Devotion in Europe c. 1215-1515. Cambridge: Cambridge University Press, 1995. 